\title{
Relevant Factors in The Post-Merger Systems Integration and Information Technology in Brazilian Banks
}

\author{
Marcel Ginotti Pires ${ }^{\dagger}$ \\ Faculdade Impacta de Tecnologia \\ Reynaldo Cavalheiro Marcondes ${ }^{\Omega}$ \\ Universidade Presbiteriana Mackenzie
}

\begin{abstract}
This article discusses the factors present in post-merger integration of Systems and Information Technology (SIT) that lead to positive and negative results in mergers and acquisitions (M \& A). The research comprised three of the largest acquiring banks in Brazil. We adopted two methods of research, qualitative, to operationalize the theoretical concepts and quantitative, to test the hypotheses. We interviewed six executives of banks that held relevant experience in M \& A processes. Subsequently, we applied questionnaires to IT professionals who were involved in the SIT integration processes. The results showed that the quality and expertise of the integration teams and managing the integration were the most relevant factors in the processes, with positive results for increased efficiency and the increased capacity of SIT. Negative results were due to failures in exploiting learning opportunities, the loss of employees and the inexpressive record of integration procedures.
\end{abstract}

Keywords: Information Systems; Information Technology; Banks; Mergers and Acquisitions; Systems and Information Technology (SIT).

*Author for correspondence:

† FIT - Faculdade Impacta de Tecnologia Programa de Graduação em Administração de Empresas

Av. Rudge, 315, Barra Funda, CEP: 01133-000, São Paulo - SP

E-mail: marcel.pires@impacta.edu.br

\footnotetext{
$\Omega$. Programa de Pós-Graduação em Administração de Empresas da Universidade Presbiteriana Mackenzie ARua da Consolação, 930 Prédio 45 CEP 01302-907 São Paulo - SP E-mail: reynaldo.marcondes@ mackenzie.br
} 


\section{INTRODUCTION}

$\mathrm{R}$ esearch on mergers and acquisitions (M\&A) have been developed through three approaches (HENNINGSSON, 2008), which are: a) as a tool for organizational strategy; study of events and activities during the processes of M\&A. Among the various stated objectives, the focus on financial aspects seems to be the primary one, although the potential earnings derived from synergies, expanding the competitive scale of the company and increasing its bargaining power being cited often.

The accelerated process of M\&A occurring in the global financial market has led to an increase in competitive pressure among financial institutions, resulting in the increase of speed in the adjustment of their respective organizational structures and processes, in particular those related to Information Technology (IT), which are indispensable to the provision of services and the operations of their businesses (PORTER; MILLAR, 1985). Particularly in Brazil, the financial sector was placed third in the ranking of M\&A in 2014, with 78 transactions involving brokers, banks and investment funds (PRICEWATERHOUSECOOPERS, 2014).

Despite this broad scope, there are few academic studies on the integration of Systems and Information Technology (SIT), which are a significant part of the investment in the case of financial institutions, especially in commercial banks, and organizational results and the management of this process in the context of M\&A (HENNINGSSON, 2008). The available literature on M\&A has shown the difficulty to assess the SIT integration process after these operations between financial institutions (JOHNSTON; YETTON, 1996; ALTUNBAS; IBÁÑEZ, 2004; COSTA, 2008). Kitching (1967) found that M\&A of the horizontal type, i.e., those between companies in the same economic sector, with approximately the same customers and suppliers, were very common among financial institutions. This type began to prevail in the 80s and 90s (CAPRON, 1999).

In financial institutions, the result of the integration of SIT provides significant economies of scale, reducing redundancy and underutilized capacity, providing synergies with this integration (ZHAO, 2006). But ultimately, what happens in the post-merger stage of the SIT? What would be involved in it? What other results, besides the economic ones, have been obtained after the merging of SIT?

Given the scenario and questions presented above, we defined the guiding research question underlying this article, which is: what factors, present in the post-merger integration of SIT, lead to positive and negative results in the event of mergers and acquisitions of Brazilian banks? In the search for the answer, this question was split into two others: a) what factors are present in the postmerger integration of SIT in the M\&A events of these institutions? b) which non-economic results have been achieved with post-merger integration of SIT? 
In the following sections of this article we present, the theoretical framework, the research strategy, which adopts the qualitative method with the application of content analysis and the quantitative method with the adoption of the structural equation modeling; then, the analyzes and conclusions.

It should be noted that this study focuses on mergers and acquisitions in commercial banks from the perspective of integration of their SIT, although the literature references used herein address, in general, the occurrence of M\&A both in banks and in the group of financial institutions.

\section{CONCEPTS ON MERGERS AND ACQUISITIONS}

M\&A are distinguished by the integration or not operations, after the process is complete (GROUP OF TEN, 2001). In the case of a merger, there is a complete integration of the two firms, control may be exercised more easily - since it involves a higher level of control - which does not occur in the acquisition, which may be partial or total. Acquisitions are most appropriate when there are operational, geographic and legal reasons to maintain the corporate structures separate, partially or completely.

Picot (2002) and Ahern and Weston (2007) argue that mergers \& acquisitions, argue that M\&As comprise the field of concentration of businesses and business cooperation and represent synonyms for agreements, such as the purchase and sale of companies, concentrations, alliances, cooperation and joint ventures, among several other types.

For Larsson and Finkelstein (1999), the synergies obtained by the company or resulting business configuration and how they relate to the company's performance is what translates the success of M\&A. Thus, synergistic benefits are related to the strategic potential of the combination, the degree of organizational integration after the deal has been completed and the low resistance of employees to the integration of joining firms. They involve the effective combination of organizational capabilities (HITT; HARRISON; IRELAND, 2001). And from most of the M\&A, it is expected to achieve significant synergies from economies of scale, rationalization of facilities and industrial plants and the elimination of legacy systems, but they all have in common the fact that they mainly require changes in IT. Activities related to IT are usually the items of higher costs in mergers or asset sales (WALSH et al., 2008).

In this article, the terms Mergers and Acquisitions are used analogously and interchangeably, in view of the research focus having been directed exclusively to the integration of Systems and Information Technology.

\section{FINANCIAL INSTITUTIONS MERGERS AND ACQUISITIONS}

M\&A are complex events that have reshaped the financial sector, which is highly competitive and dynamic, and represent a growing trend in the market (GROUP OF TEN, 2001). M\&A have 
accelerated the consolidation of the banking sector, in response to the need for banks to be bigger, more diverse and offer more comprehensive services to compete globally (KEELER, 2000). They are part of the organizational strategies to achieve the objectives of growth and diversification that cannot be obtained within the limited time that organic growth allows (MERALI; McKIERNAN, 1993).

Marco, Giustiniano and Rajola (2000) points out that the declared purpose of banking M\&A is always expressed by obtaining significant competitive advantage through the exploitation of synergies permitted by large sizes, i.e., economies of scale and economies of scope, with the capture of these synergies representing one of the most important reasons for the M\&A operation. Achieving economies of scale is possible by sharing the central infrastructure, standardization of software, the provision of common services or simply by increasing the bargaining power.

Evaluating horizontal acquisition events which occurred in Brazil, from the 90s to 2002, we verified that the banks Bradesco, Itaú and Unibanco, which have become habitual acquirers, have achieved efficiency and increasing financial gains in the integration processes from new acquisitions (CARVALHO; STUDART; ALVES, 2002). The observation that regular acquirers can obtain efficiency and increasing financial gains was also demonstrated by other researchers (HALEBLIAN; KIM; RAJAGOPALAN, 2006; ZOLLO; SINGH, 2004).

\section{SYSTEMS AND INFORMATION TECHNOLOGY}

IT can be defined as the assets in computing and communication technologies, including hardware, software, telecommunications and a variety of devices that collect and process data, all electronically stored, and the people involved in providing services. In addition to these, it includes investments in IT implemented by internal groups and those provided by other suppliers (WEILL; BROADBENT, 1998; WIJNHOVEN et al., 2006; TURBAN; MCLEAN; WETHERBE, 1999).

Albeit ownership of IT resources not being considered as a factor of creation of sustainable competitive advantage for companies (PORTER; MILLAR, 1985), it represents an essential factor for banking competitiveness. The value of IT is associated with the way of it being used in the search for competitive advantage, providing support for the organizations business strategies (BROWN; HAGEL III, 2003).

Integration is a common term in the literature of business systems, although it is used both in academia and in business and describes a process, a condition, a system and a final state (GULLEDGE, 2006). We highlight that it is the post-merger integration of SIT, which represents the main source of potential value for M\&A, increasing its strategic relevance (JOHNSTON; YETTON, 1996; ALARANTA, 2005). Thus, SIT integration must be understood as the dynamic 
relationship of the integration of ISs and the context of M\&A and the action of environmental pressure on the solution integration (HENNINGSSON; CARLSSON, 2007).

And information systems are integrated aimed at creating consistent systems with those easier business process flows, demonstrating information in a unified manner in order to support management and administrative decisions makers (MENDONZA; PEREZ; GRIMAN, 2006). And making good decisions on the integration of SIT in companies requires a thorough knowledge of information systems, experiencing a loss of investment if the legacy systems of the acquirer and the acquired cannot be integrated (ZHAO, 2006).

During the implementation of integration, higher costs happen with the conversion of software, with the consolidation of hardware and communication being relatively simpler and provides great economies of scale (CARLYLE, 1986). The integration of the two SIT does not necessarily imply that a single system, environment and software architecture are chosen, and exchange of data and organizational processes may occur, according to the needs of merged organizations (GIACOMAZZI et al., 1997).

Wijnhoven et al. (2006) highlight that there are three IT integration objectives, which are: a) complete integration; b) partial integration; and c) marginal integration (or coexistence). With respect to the complete integration, it is performed through the renewal, which involves the complete design of new processes and the related IT (GOUILLART; KELLY, 1995), choosing the SIT of one of the companies, which can avoid IT redundant costs, the choice of the best parts of the IT as a new standard, also referred to as "best-of-breed" selection, and coexistence and synchronization, which keeps everything as it was, generating only a marginal integration between the IT structures of the organizations, which are preserved.

\section{INFLUENCING FACTORS IN THE POST-MERGER INTEGRATION OF SIT}

Initially, we conducted a broad survey involving the topics of M\&A, the IT environment of banking organizations and those related factors relevant to the successful integration of SIT. Subsequently, all the identified factors were inserted into a spreadsheet, in which the works and their authors were related. Thus, it was possible to identify those that appear most frequently in the literature, revealing a greater thematic consistency. From this table and the appearance of the factors, we selected those with a greater association with the objectives and topics covered.

From the conducted survey, and those identified in the theoretical framework presented in this article, it was possible to identify six factors of SIT integration assumed to be relevant, namely: a) the alignment of IT with business strategy; b) the configurations of SIT; c) the infrastructure/ architecture of SIT; d) technical and business expertise and which is linked to previous experiences; e) and quality/expertise of the team involved in the integration and f) integration management. 
However, it should be noted that the six factors do not appear on any of the articles together, highlighting the difficulties of obtaining, in the literature, broader perspective of the integration of SIT within the M\&A processes involving banking financial institutions. Once such factors are identified, and based on the performed literature review, we sought to build exogenous constructs of integration (hypotheses H1 to H6), shown in Table 1.

The strategic alignment of IT represents its suitability to business strategy, structure and processes of a company (MORTON, 1991), defining a number of strategic choices, as well as being very important (MCAFEE, 2006). It can be understood as a continuous process of adaptation and change, based on two fundamental dimensions, denominated Integration / Strategic Adaptation and Functional Integration. These two dimensions define four areas of strategic choices of which two have been highlighted in this article: a) It strategy, defined in terms of choices relevant to the business position in the IT market; and b) infrastructure of the SIT (HENDERSON; VENKATRAMAN, 1989).

Configuration of Information Systems (IS) is a formal representation of the size of these systems, including structural contingencies, management processes and positions of people and authors holding this role, and their users in the company (BRUNETTO, 2007). The postmerger integration of IS consists of two complementary and sequential aspects, which are the possible ways of integration and implementation of the chosen integration mode. Brunetto (2007) proposed a typology for the emerging mode of integration of IS, based on two strands: the degree of compatibility of the IS configuration and the strategic objectives assigned to it.

Johnston and Yetton (1996) assert that the differences in SIT configurations of banks involved in M\&A processes influence the integration strategies between their IT areas. In the study conducted by authors, the SIT configuration was used to define the organizational strategy environment, structure, processes management, technology, skills/individual positions which constitute the SIT function within a company.

Para Giacomazzi et al. (1997), IT requirements directly influence the configuration and architecture of SIT and, consequently, the integration strategies, through economies of scale (imposed by the centralized computer system), operating behavior consolidation (help in developing similar organizational cultures by standardization of business processes) and the integration of data/standardization of reports (promotes the standardization of information management and data representation).

With regard to infrastructure and technological architecture, the IT portfolio is a result of the long-term infrastructure of the company (BROADBENT; WEILL, 1997). An architecture is an integrated set of technical choices used to support the organization in meeting business needs. It comprises a set of policies and rules governing the use of IT and plans a path to the business model 
that will be elaborated in the future. Weill and Broadbent (1998) argue that companies that spend more on IT infrastructure have more services, and that the creation of appropriate services involves decisions based on the vision of company management.

Byrd and Turner (2001) identified a positive relationship between the infrastructure of SIT and the company's competitive advantage over competitors, concluding that the flexibility of IT staff contributes significantly to the flexibility of the infrastructure. Regarding the staff, we regard as relevant, the magnitude and quality of knowledge, their individual skills and experience in the development of the main application systems of the company.

An IT architecture is required to obtain compatibility between multiple systems, specify the policies and mechanisms to meet the IT strategy, describing the technological model of the company (WEILL; BROADBENT, 1998). In addition, a high integration can result in the standardization and data sharing between applications, and may produce synergistic results more easily (ROBBINS; STYLIANOU, 1999).

Knowledge may refer to the customer of the financial institution (PIRES; MARCONDES, 2004) or the knowledge held by employees on work processes, administrative practices, operating methods and characteristics and its own organizational culture, involving tacit knowledge. Knowledge was defined by Turban et al. (1999) as data or information that has been organized and processed to express understanding, experience, accumulated learning and expertise on how they apply to a problem or opportunity. Davenport and Prusak (1998) recognize the existence of two types of knowledge, the explicit and tacit. The explicit comprises what is usually described as knowledge, such as written words or mathematical formulas. Tacit is one that is understood without being expressed directly and is the dominant principle of all knowledge (POLANYI, 1983).

Previous experience with M\&A, understood as the number of acquisitions completed by the acquiring company before the acquisition in question, is considered important because it is associated with the learning curve and the degree of coding that knowledge (ZOLLO; SINGH, 2004). Moreover, it is an important success factor of integrations (STYLIANOU et al., 1996).

As for the quality/expertise of integration teams, this has been a recurring factor in the success of integration of SIT, whether of the performance of managers, or the technical team that constitutes the staff (ALARANTA, 2005; HARREL; HIGGINS, 2002), because there are always losses in these processes. In addition to the higher levels of management, another aspect considered as critical to the success of SIT integration is the maintenance of staff. There is the risk of losses of these people jeopardizing or undermine the processes of corporate absorption, particularly if the acquiring company does not have the necessary knowledge about the systems in the acquired company. 
Regarding integration management, Alaranta (2005) emphasizes the search for efficiency and effectiveness of the integration of SIT, so that the use of time, cost and staff resources are productive and effective during the process. Cartwright and Cooper (1996) emphasize that one of the most important factors for the success of M\&A that determine its speed and effectiveness, are related to how the integration process is managed. The management of integration of SIT includes some topics that, when combined, contribute positively to success, such as the integration degree, integration planning activities, development of integration priorities, the objectives and the degree of participation of SIT staff involved in planning the merger positively impact on its success (STYLIANOU; JEFFRIES; ROBBINS, 1996).

In relation to the staff involved in the integration, Stein (1993) lists some factors as being important to its success, such as: a) the selection of a dedicated team, segregated from the daily operations of the bank; b) the incentive for the entrepreneurial initiative of the teams involved; c) setting realistic goals; d) definition of deadlines and its fulfillment, and e) allocation of all resources, money and technology necessary for project completion.

\section{RESULTS OF POST-MERGER SIT INTEGRATION}

The second issue addressed in the research focused on the results generated by the process of post-merger SIT integration. In this case, it was quite difficult to identify specific work on the results of the post-merger of SIT in M\&A banking processes. We assume that it is because in general, the SIT integration results are recorded as part of the bigger event of M\&A. Even with this difficulty, we found that the authors seek to identify these events, whether the expected earnings and economic advantages of the banking concentration were actually achieved in the period prior to M\&A, under the financial perspective. This has been the common practice because there are well-defined metrics that can be used (JOHNSTON; YETTON, 1996; COSTA, 2008; ALTUNBAS; IBÁÑEZ, 2004), but to identify the contribution of the integration of SIT for business is an additional difficulty.

The result of the integration, success or failure, can be shown in different ways (ROBBINS; STYLIANOU, 1999; GIACOMAZZI et al., 1997; McKIERNAN; MERALI, 1995). The success of the SIT integration is an ambiguous and multifaceted outcome, which makes it problematic to identify or determine reliable measures (ALARANTA, 2005).

Alaranta (2005) proposes four components to evaluate the success of the post-merger integration, which are: a) user satisfaction with the integrated system software and the quality of information, as well as its usage, so that no inconvenience is caused to customers, provide access to information throughout the organization, besides the accuracy, utility and information at the right 
time; b) efficient and effective management of integration of SIT (identified as a success factor of integration); c) efficient integration of the staff of SIT (success factor of integration); d) SIT skills integrated in meeting the motivations of M\&A, such as: cost cutting and reducing redundancies in light of SIT and better coordination of production capability, among others.

Stylianou et al. (1996) and Robbins and Stylianou (1999) consider success in the integration of SIT as a multidimensional attribute which can be verified through measures, such as: a) increasing the capacities of SIT to guarantee fundamental reasons for M\&A; b) efficiency and effectiveness of resource use in the integration process; c) ability to exploit opportunities arising from integration; d) abilities to reduce the resistance to the integration; and e) end-user satisfaction with the process of integration and integrated systems. Marco, Giustiniano and Rajola (2000) highlights that cost reduction in $\mathrm{M} \& \mathrm{~A}$ among banks is related to the infrastructure of SIT, transferring competences, know-how and procedures from one company to the other, exploring other economies of scope.

Also highlights that a high level of integration of SIT seems to be particularly suitable when the acquiring bank imposes its SIT to the acquired bank, leaving its management centralized. In this case, the SIT of the bank acquired are discontinued, and this area ends up centralized in the acquiring bank, in order to achieve economies of scale.

For survey purposes, the positive results of the post-merger integration were defined as: a) impacts on teams of SIT; b) increased efficiency of SIT; c) user satisfaction; d) lower operating costs; e) increased capacity of SIT; f) improved use of resources; g) improving the quality of SIT.

The difficulties of SIT integration among companies involved in M\&A are often attributed to different operating philosophies, different management practices, administrative procedures and communication styles, of those responsible. It is critical for the acquiring company to determine how it can integrate processes and services to internal and external customers and obtain the synergistic opportunities for mergers between organizations, for this to happen, it must meet several critical success factors, such as maintaining a high standard of staff (HARRELL; HIGGINS, 2002).

Often, the problems arising from the integration are caused by the adopted choices after the M\&A process. Giacomazzi et al. (1997) highlight that these can be technical and organizational. Technical problems are due to the integration of the components of SIT and any data insufficiency. Organizational problems depend mostly, on organizational culture, which are more difficult to resolve and often underestimated, bringing serious implications for the efficient use of hardware and software.

McKiernan and Merali (1995) claim that the failure to pay attention to the strategic functions of SIT in M\&A makes it difficult for some companies to exploit their proactive capabilities to transform and reposition the organization in its competitive environment, jeopardizing the 
quality of corporate informational infrastructure and product quality. Failures to explain future expectations on the current staff of SIT can result in qualified staff losses. Mehta and Hirschheim (2007) emphasizes that the integration of functions of SIT may result in expenses higher than the reduced costs, when it is not focused on the prospect of efficiency by managers.

In the face of what was treated in this item, we defined to adopt as negative results of the integration of SIT: a) the increased cost of IT; b) the negative impact on SIT teams; c) reducing its efficiency; d) failure to explore learning opportunities.

\section{RESEARCH METHODOLOGY}

Based on the theoretical basis of the two basic constructs resulting from the research question, we defined the model of the survey, in which the independent variable was the one referring to "active factors in the integration of SIT", and the dependent variable, the "results in the postmerger stage".

Therefore, research strategy includes the adoption of two different methods, but used in a complementary way, at different stages. At first, an exploratory research qualitative was performed with the objective of making the study variables easier to operationalize, conceptualized in the Theoretical Framework. The second was descriptive of quantitative nature, in which we tested the developed hypotheses in the first stage (COLLIS; HUSSEY, 2005).

\subsection{QUALITATIVE STAGE}

This stage was devoted to understanding the reality of the occurrence of these two variables, aimed at formulating the quantitative tool for data collection. We opted for the qualitative method because it deals with a specific environment. Thus, we sought to understand the meanings of postmerger integration before those who participated in this process, so that communication could be more productive and revealing of the relevant aspects on practices of participants (FLICK, 2004).

\subsubsection{THE SUBJECTS OF THE QUALITATIVE RESEARCH AND DATA COLLECTION}

We interviewed six executives belonging to banks involved in M\&A processes that held relevant experience in SIT integration processes with banking institutions and in managing large technical teams, working at a strategic level during the banking integration process. In the interviews we used a standardized script with 17 open questions. The duration of interviews were between one and two and a half hours. 
The questions were formulated based on integration factors and outcomes, defined in the previous item, that determined the pre-categorization of data, with the interviews having been preceded by a pre-test to ensure greater reliability in surveys (FLICK, 2004). All of them were transcribed verbatim for its analysis.

The research focused on retail banking, selected according to the following criteria: a) they have national presence; b) are related among the ten largest banks in financial assets of the country (EDITORA ABRIL, 2010); c) no restrictions on capital control (private national, international or state); d) have participated in a process of M\&A from other banks. Given the required condition of confidentiality, the names of the banks could not be revealed in this article.

\subsubsection{TREATMENT OF QUALITATIVE DATA}

Treatment of statements began with the application of lexical and semantic analyses, aimed at the construction of categories, according to the procedures of Content Analysis (BARDIN, 2007). It consisted of a continuous process of reading and rereading, disintegration and combination of themes identified from the analyzes (FLICK, 2004). The last stage of content analysis resulted in the identification of 14 eligible categories based on interviews. Out of these, 10 represented preexisting categories, and 4 emerged from the work performed.

The observed preexisting categories were: 1) Organizational experiences; 2) Knowledge derived from previous experiences; 3) Quality of professionals of SIT; 4) Management Models; 5) Strategic alignment between IT and business areas; 6) Infrastructure of SIT; 7) Architecture of SIT; 8) Configuration of SIT; 9) Observed positive results; 10) Observed negative results. Emerging categories were not addressed in the development of the work. They are: 1) Definition and implementation of integration strategies; 2) Paying attention to customers; 3) Leadership and, 4) Risks in integration. As a result of this procedure, it was possible to understand more clearly the meaning of the various factors and results.

\subsection{QUANTITATIVE STAGE}

In the next stage we formulated the hypotheses based on existing categories previously listed in the qualitative part, to be subjected to tests, identified in Table 1. 
Table 1. Hypotheses of the study. Source: developed by the authors.

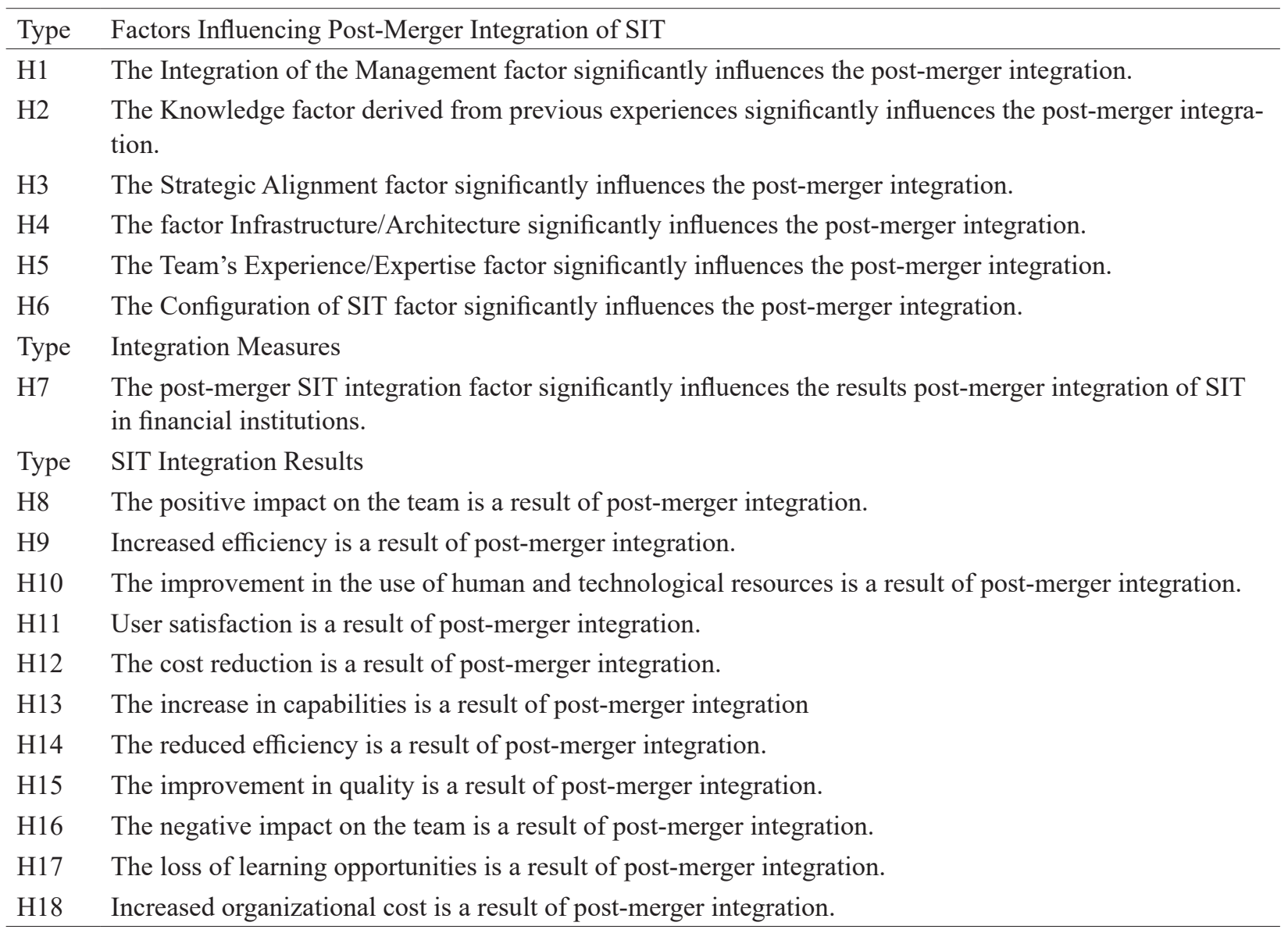

\subsubsection{THE SUBJECT OF THE QUANTITATIVE RESEARCH AND DATA COLLECTION}

The quantitative research was conducted with SIT professionals who were formally involved in the integration processes in their respective banks, except for those who participated in the first stage. The standard respondent was the professional with wide experience and vision of SIT, occupying management positions or who had led integration activities, or been a participant in technical management teams, linked to the development and maintenance of SIT, with a minimum of ten years of experience.

The questionnaire consisted of 107 questions, with a return of 72 valid questionnaires. Respondents had the following profile: 15 division managers, 35 managers and team coordinators and 22 senior analysts who participated in the management team or of SIT and led teams during the integration activities. Before being applied to these professionals, the questionnaire was submitted to five professionals from SIT and three academic experts in the areas of IT and strategy, so they could make suggestions for adjustments and improvements. 
Regarding the number of concepts and constructs, this model used 18, being within the range considered as appropriate by Hair et al. (2005) that the interpretation of results, particularly of statistical significance, it becomes very difficult, as the number increases, exceeding 20. Furthermore, the number of variables per construct did not exceed 10 (for each one of them). Regarding the minimum amount of the quantitative sample (number of questionnaires), Henseler, Ringle and Sinkovics (2009) emphasizes that it is acceptable 10 times as many paths directed to a particular construct in an internal path model, such a situation is met by the existence of the six paths, totaling a minimum of 60 questionnaires. Hair et al. (2005) asserts that the number of questionnaires for the formative latent variables must lie between five and ten for each one of them. In the proposed model, this number is 12 , which would require from 60 to 120 questionnaires, and is also within an acceptable range.

\subsubsection{QUANTITATIVE DATA TREATMENT}

We applied the multivariate data analysis technique, Structural Equation Modeling (SEM), which assumed a confirmatory approach to the analysis of a structural theory based on the relationship between phenomena. The hypotheses were tested in simultaneous analysis within the entire system of variables, to determine the consistent extension between data (BYRNE, 2001).

For the structural equation modeling to be considered valid, many items had to be evaluated, such as the consistency and internal reliability, among others. Thus, we analyzed some indicators and quality criteria, such as: Cronbach's Alpha, average variance explained and the composite reliability, although a "[...] high reliability does not guarantee that a construct is representing what it should. It is a necessary condition but not sufficient for validity." (HAIR et al., 2009, p.540). The reliability represents: "[...] $]$ an indicator of the degree to which a set of indicators of a latent construct is internally consistent based on how highly interrelated the indicators are." (HAIR et al., 2009, p.544). On the construct, Hair et al. (2009, p.591) defines its validity as "[...]the degree to which a set of items measured truly reflects the theoretical latent construct that those items should measure."

We also attempted to validate the structural model through the distribution of Student's t-test analysis, obtained by implementing the bootstrapping technique available in the Smart PLS software.

\subsubsection{APPLICATION OF THE STRUCTURAL EQUATION MODELING}

Within the SEM, we opted for the use of the PLS (partial least square) path model technique (HENSELER; RINGLE; SINKOVICS, 2009). PLS was used because the research model was 
consistent with its use specifications, such as: a) availability of a sample containing 72 valid questionnaires; b) model with many variables and constructs; c) formative measurement model; and d) the scores of the measured constructs for several indicators (manifest variables).

Figure 1 represents a graphic display of relationships, termed as paths diagram. We can observe exogenous constructs (independent variables) and endogenous. Exogenous constructs are not caused or predicted by any other variables in the model, i.e., there no arrows pointing at these constructs. Endogenous constructs are those predicted by one or more constructs, with arrows pointing at them. We can observe in Figure 1, that the resulting structural model presents its first order constructs of reflective nature.

After having identified the most common positive and negative results discussed in the SIT integration literature, we selected those that relate to the integration of SIT and that appeared most often in the studied literature. Thus, it was they who originated the various constructs adopted in the structural model and, for each one of them, we proposed a hypothesis (H8 till H18), whereas hypothesis H7 was proposed for the integration variable, seen in Figure 1.

The operationalization of the constructs represented an additional difficulty. For the constructs included in the survey, we used 107 indicators described by Pires (2011). Because of space limitations, we opted not to detail these indicators. The indicators that appear in this article represent those that were not rejected in the the validation tests performed, which were the following (PEREZ, 2006): a) internal consistency test (Cronbach's Alpha); b) AVE (average variance extracted) on Smart PLS); c) composite reliability test; and d) correlation between variables and their constructs.

The structural model was evaluated by the coefficient of determination R2 (R-squared) of the endogenous latent variable (INTEGRATION), whose final value was 0.235 , which are moderated values (CHIN, 1998).

Based on the criteria listed above, we proceeded to an initial processing of the Smart PLS 2.0 M3 software. Later, adjustments were made in the original model proposed, with the variables that presented inadequate correlation being extracted. We also excluded the constructs with Cronbach's alpha values below 0.7, according to Henseler, Ringle and Sinkovics (2009) and with composite reliability at levels considered as not acceptable. Again we ran the PLS processing.

By excluding four constructs (HAIR et al., 2005) from the model, for not presenting acceptable internal consistency, it prevented us from testing the following hypotheses: H10 "The improvement in the use of human and technological resources is a result of the post-merger integration of SIT"; H14 - "The reduced efficiency is a result of the post-merger integration of SIT"; H16 - "The negative impact on the team is a result of integration"; and H18 - "The increase in organizational cost is a result of post-merger integration". 


\subsubsection{VALIDATION OF THE STRUCTURAL MODEL}

After we adjusted the model, we performed the bootstrapping, available on the Smart PLS software, with the parameter of 500, both for the number of cases as for the number of samples, to conduct the Student's t-test distribution. A sample with 72 questionnaires has 71 degrees of freedom, and, for this degree of freedom, the value of the Student's t distribution was 1.99, for a $95 \%$ confidence interval. The significance level in this case was 5\% (0.05), according to Bussab and Morettin (2003), showing that the existing correlation is significant. Therefore, if Student's t-test results were lower than 1.99 , the hypothesis would not have been verified, causing the existing correlation to be significant. However, Student's t values obtained for the construct EXPERIENCE (1.857) and for the construct ALIGNMENT (1.749), for being close to the limit, they were considered as acceptable, resulting in these two constructs not being rejected.

Figure 1 demonstrates the result of running the bootstrapping process that conducted the Student's t-test.

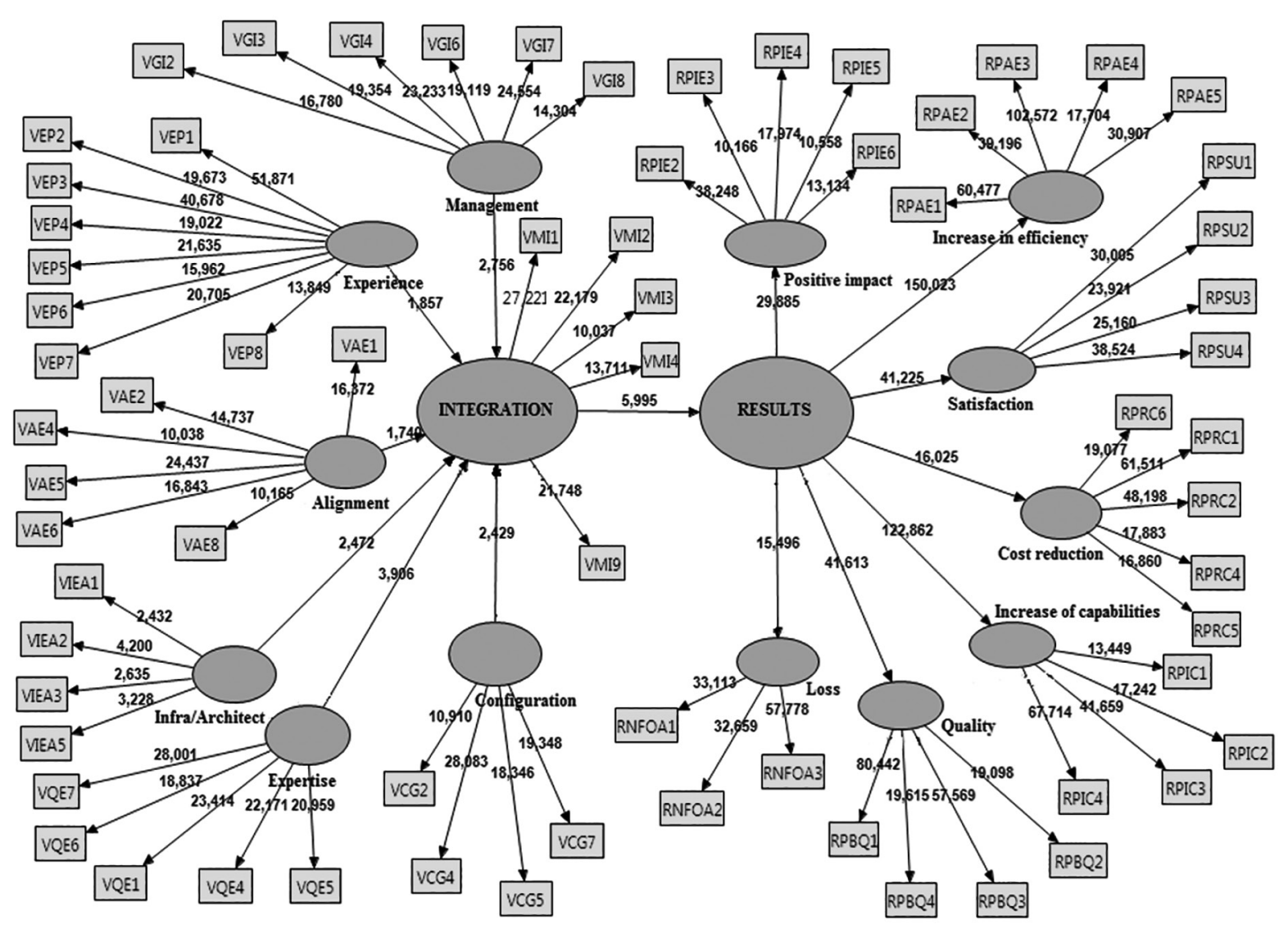

Figure 1. Model after the Smart PLS processing by using the bootstrapping technique. Source: developed by the authors. 


\section{RESULTS}

Once the model's qualitative analysis was finished, after the Smart PLS processing with the bootstrapping technique, we obtained Table 2, which shows the results of the analysis of the proposed conceptual model, containing Cronbach's alpha and Student t-Test values.

Table 2: Results of the analysis of the proposed model: complete sample

\begin{tabular}{lccccc}
\hline \multicolumn{2}{l}{$\begin{array}{l}\text { Results of the analysis }- \text { complete sample - PLS } \\
\text { Construct's Causal Relationship }\end{array}$} & Cronbach's Alpha & Hypothesis & $\begin{array}{c}\text { Student's t-Test } \\
\text { values }\end{array}$ & $\begin{array}{c}\text { Hypothesis } \\
\text { Rrom }\end{array}$ \\
To & & & & 2.756 & Not rejected \\
\hline Management & INTEGRATION & 0.791793 & H1 & 1.857 & Not rejected \\
Experience & INTEGRATION & 0.878422 & H2 & 1.749 & Not rejected \\
Alignment & INTEGRATION & 0.785834 & H3 & 2.472 & Not rejected \\
Infra / Archi & INTEGRATION & 0.766986 & H4 & 3.906 & Not rejected \\
Expertise & INTEGRATION & 0.800926 & H5 & 2.429 & Not rejected \\
Configurations & INTEGRATION & 0.720817 & H6 & 5.995 & Not rejected \\
INTEGRATION & RESULTS & 0.742186 & H7 & 29.885 & Not rejected \\
RESULTS & Pos-impac & 0.700926 & H8 & 150.023 & Not rejected \\
RESULTS & Inc-efici & 0.857023 & H9 & ----- & Not tested \\
RESULTS & Impr-utili & 0.320000 & H10 & 41.225 & Not rejected \\
RESULTS & Satisfaction & 0.803657 & H11 & 16.025 & Not rejected \\
RESULTS & Cost-reduction & 0.788627 & H12 & 122.862 & Not rejected \\
RESULTS & Incre-Capac & 0.718406 & H13 & ----- & Not tested \\
RESULTS & Reduc-efici & 0.547601 & H14 & 41.613 & Not rejected \\
RESULTS & Quality & 0.794021 & H15 & ----- & Not tested \\
RESULTS & Neg-impac & 0.389859 & H16 & 15.496 & Not rejected \\
RESULTS & Loss & 0.772702 & H17 & ----- & Not tested \\
RESULTS & Inc-cost & 0.617174 & H18 & &
\end{tabular}

Figure 2 shows a summary of what we obtained in the relationship between the variables used in the study of the model. We can observe that the width of the arrows and the values associated with each indicates the relevance of the factors in the post-merger integration of SIT and the results of this integration.

\section{CONCLUSIONS}

Returning to the initial question of this article on which factors, present in the post-merger integration of SIT, lead to positive and negative results in M\&A of Brazilian banking institutions, it is possible to say that the quality and expertise of integration teams, followed by the integration of management, were the most important factors in the process, having produced the most significant positive results, the increased efficiency of SIT and the increased capacity of SIT. 


\section{Final Model Validated}

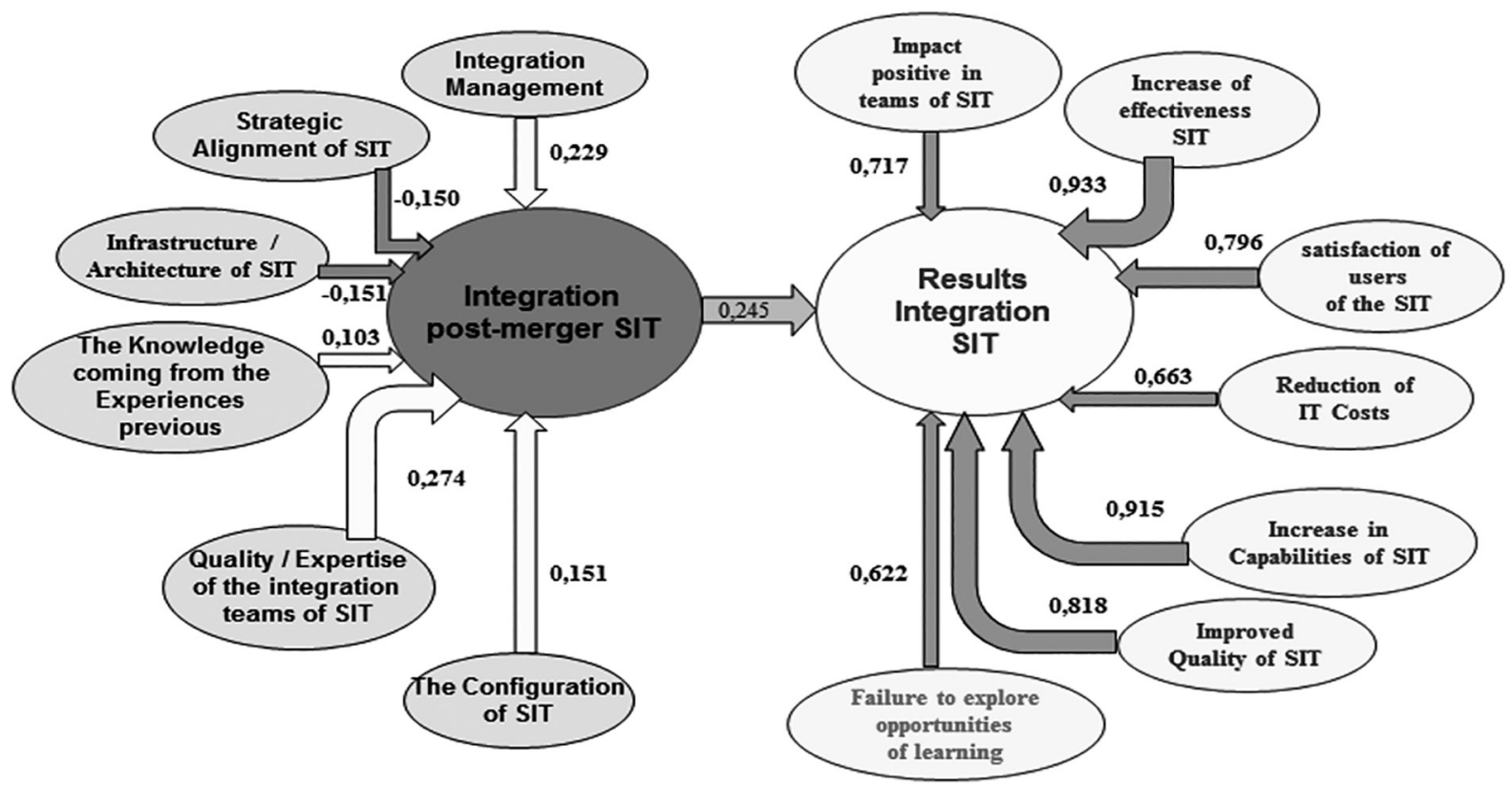

Figure 2. Validated final model. Source: Developed by the authors.

The quality and expertise of the technical integration teams had to do with the needs of a thorough knowledge of the technical characteristics of SIT and how business rules are embedded within these SIT, which led to the preservation of the technical teams of the acquired banks.

The management of integration involves the establishment and implementation of organizational strategies, control of the implementation of these strategies and the management of technical integration activities, evidenced by an active governance, with emphasis on planning and efficient communication between banks involved in M\&A, in addition to the development of the single team concept between the technical teams involved.

The factors, in descending order of relevance, configurations of SIT, knowledge from previous experiences, strategic alignment and infrastructure/architecture, appeared as far less influential, due to the similarity between the hardware and software resources between the SIT object of the merger.

The similarity of the hardware and software resources helps mainly the speed of integration and the reduction of technical problems that impact the continuity of these activities. In addition, the ease of communication between the various technologies that were updated substantially reduced the difficulties of integrating caused by various SIT configurations. Effectively, this similarity was largely responsible for reducing the importance of other factors, because the prior tacit knowledge 
of the professionals was very similar. It also facilitated the perceptions and dimensioning the impacts of factors present in the integration.

Neither did we perceive the strategic alignment as relevant, and in relation to infrastructure, the acquiring banks have chosen to disable those of the acquired banks.

As for the positive results, increased efficiency results from the way, apparently appropriate, in which customers' data, operations and transactions of the acquired bank migrated without this causing significant technical problems or undermining the operations of SIT of the acquiring banks. Similarly, the development of their capabilities, indicating that the acquiring banks were able to rapidly escalate supporting the growth of transactions and operations occurred. A third less expressive result, but with a certain relevance, was the improvement in the quality of SIT by the accuracy of the information given to acquiring banks, made available at the appropriate time and that proved useful for acquiring banks, whose SIT were adjusted to contain several existing functionalities in the acquired banks.

With less intensity, the results in relation to users satisfaction had to do with the integration processes that took place with few problems and disruptions, but that did not affect their services.

The results, impact on teams of SIT and reduce IT costs, surprisingly received the lowest values, contradicting what the literature exposes. Despite the reduction of IT costs not having appeared as the main result or objective of the integration of SIT, the increase of efficiency and processing capabilities of the institutions became evident, as a resulting improvement in the quality of SIT.

As a negative result, the failure to explore learning opportunities may be cited, made evident by the inexpressive record of the integration process and the loss of some staff with great knowledge of SIT who left the banks.

Among the limitations of the study, it is worth referring to the response number in the quantitative stage, leading to possible questions, keeping in mind the non-convergence of views between research methodology authors.

This research's major contribution for the literature was the comprehensiveness of the performed analysis, focusing on both the factors affecting the integration of SIT as the positive and/or negative perceived in the sample banks, using this, two research methods supported on the methodological triangulation technique, creating the possibility for it to be fully or partially replicated, either combining or not the two approaches. The questions can be reviewed and adjusted to the desired focus, but run by a validated previous model.

As a final assessment, it can be affirmed that the integration processes of SIT for the banks that were the object of research, were successful when considering the way the resources and skills were conducted within the M\&A strategies. Thus, the work has the merit to present the factors in 
great organizations, which can in a wide-range affect the very process of $M \& A$, as well as its results and that would serve as a warning to managers involved in these complex events.

As a suggestion of topics for future studies, the model could be better exploited in terms of financial returns of the integration of SIT, which are more difficult to be obtained in technical areas, expanding the study of the results of integration.

\section{REFERENCES}

AHERN, K. R.; WESTON, J. F.M\&As: The Good, the Bad, and the Ugly. Journal of Applied Finance, v.17, n.1, p.5-20, Spring/Summer, 2007.

ALARANTA, M. Evaluating success in post-merger IS integration: a case study. The Electronic Journal of Information Systems Evaluation, v.8, n.3, p.143-150, 2005.

ALTUNBAS, Y.; IBANEZ, D. M. Mergers and Acquisitions and Bank Performance in Bank Performance in Europe: The Role of Strategic Similarities. European Central Banking. WorkingPaper Series n. 398, Outubro, 2004. Disponível em: <http://www.ecb.int/pub/pdf/scpwps>.

BARDIN, L. Análise de conteúdo. Lisboa: Edições 70, 2007.

BYRNE, B. M. Structural equation modeling with AMOS: basic concepts, applications and programming. New Jersey: Lawrence Erlbaum, 2001.

BROADBENT, M.; WEILL, P. Management by maxim: how business and IT managers can create IT infrastructures. Sloan Management Review, v.38, n.3, p.77-92, 1997.

BROWN, J. S.; HAGEL III, J. Does IT Matter? Harvard Business Review, v.81, n.7, p.109$112,2003$.

BRUNETTO, G. Integrating Information Systems during mergers: integration modes typology, prescribed vs. constructed implementation process. Proceedings of the Ninth International Conference on Enterprise Information Systems. Funchal, Madeira, Portugal, 2007.

BUSSAB, W. O.; MORETTIN, P. A. Estatística Básica. 5a. ed. São Paulo: Saraiva, 2003.

BYRD, T. A.; TURNER, D. E. An exploratory examination of the relationship between flexible IT infrastructure and competitive advantage. Information and Management, v.39, n.1, p 41-52, 2001.

CAPRON, L. The Long-Term Performance of Horizontal Acquisitions. Strategic Management Journal, v.20, n.11, p. 987-1018, 1999.

CARLYLE, R. E. Mergers: a raw deal of MIS. Datamation, v.32, n.18, p. 60-64, 1986.

CARTWRIGHT, S.; COOPER, C. L. Managing mergers, acquisitions and strategic alliances: integrating people and cultures. 2ed. Oxford: Reed Educational and Professional Publishing, 1996.

CARVALHO, C. E.; STUDART, R.; ALVES, A. J. JR. Desnacionalização do setor bancário e financiamento das empresas: a experiência brasileira recente. Brasília: IPEA, 2002.

CHIN, W.W. The partial least squares approach to structural equation modeling. In: MARCOULIDES, G.A. Modern methods for business research. NJ: Lawrence Erlbaum, 1998. 
COLLIS, J.; HUSSEY, R. Pesquisa em administração: um guia prático para alunos de graduação e pós-graduação. 2.ed. Porto Alegre: Bookman, 2005.

COSTA, J. V. da. JR. Retornos anormais versus performances operacionais anormais de firmas brasileiras envolvidas em fusões e aquisições no período de 2002 a 2006. Tese de Doutorado. Universidade de São Paulo, SP, Brasil. 2008.

DAVENPORT, T. H.; PRUSAK, L. Conhecimento empresarial: como as organizações gerenciam o seu capital intelectual. Rio de Janeiro: Campus, 1998.

EDITORA ABRIL. Revista Exame: melhores \&maiores, 42, jul., 2010,p. 350-351, São Paulo, SP.

FLICK, U. Uma introdução à pesquisa qualitativa. 2. ed. Porto Alegre: Bookman, 2004.

GIACOMAZZI, F.; PANELLA, C.; PERNICI, B.; SANSONI, M. Information systems integration in mergers and acquisitions: a normative model. Information and Management, v.32, n.6, p.289-302, 1997.

GOUILLART, F.; KELLY, J. Transforming the organization. New York: McGraw Hill, 1995.

GROUP OF TEN. Report on Consolidation in the Financial Sector ("Ferguson Report").2001 January. BIS/IMF/OECD. Recuperado de <https://www.imf.org/external/np/g10/2001/01/eng/ pdf/file1.pdf $>$. Acesso em: 15março2015.

GULLEDGE, T. What is integration. Industrial Management and Data System, v. 106, n. 1, 2006.

HAIR, J. F.; BLACK, W. C.; BABIN, B. J.; ANDERSON, R. E.; TATHAM, R. L. Análise Multivariada de Dados, 6 ed. Porto Alegre: Bookman, 2009.

; ANDERSON, R. E.; TATHAM, R. L.; BLACK, W. C. Análise Multivariada de Dados. 5 ed. Porto Alegre: Bookman, 2005.

HALEBLIAN, J.; KIM, J.; RAJAGOPALAN, N. The influence of acquisition experience and performance on acquisition behavior: evidence from the U.S. commercial banking industry. Academy of Management Journal, v.49, n.2, p.357-370, 2006.

HARRELL, H. W.; HIGGINS, L. IS integration: your most critical M\&A challenge? Journal of Corporate Accounting and Finance, v.13, n.2, p.23-31, 2002.

HENDERSON, J. C.; VENKATRAMAN, N. Strategic alignment: a framework for strategic information technology management. Centre for Information Systems Research. CISR working paper n.190, Massachusetts Institute of Technology, Cambridge: Massachusetts, 1989.

HENNINGSSON, S. Managing information systems integration in corporate mergers and acquisition. Lund: Lund Business Press, 2008.

; CARLSSON, S.A. The dynamic relation between is integration and the merger and acquisitions. In: Proceedings of the $13^{\mathrm{TH}}$ Asia Pacific Management Conference. Australia: Melbourne, 2007.

HENSELER, J.; RINGLE, C. M., SINKOVICS, R. R. The use of partial least squares path modeling in international marketing. Advances in International Marketing, v.20, p.277-320, 2009.

HITT, M. A.; HARRISON, J. S.; IRELAND, R. D. Mergers and Acquisitions: a guide to creating value for stakeholders. New York: Oxford University Press, 2001.

JOHNSTON, K. D.; YETTON, P. W. Integrating information technology divisions in a bank merger: fit, compatibility and models of change. Journal of Strategic Information Systems, v.5, n.3, p.189-211, 1996. 
KITCHING, J. Why do mergers miscarry? Harvard Business Review. Nov-Dec, 1967.

KEELER, D. Banking in the $21^{\text {st }}$ century. Global Finance, v.14, n.1, p. 41, 2000.

LARSSON, R.; FINKELSTEIN, S. Integrating Strategic, Organizational, and Human Resource Perspectives on Mergers and Acquisitions: A Case Survey of Synergy Realization. Organizational Science, v.10, n.1, p. 1-25, 1999.

MARCO, M. de; GIUSTINIANO, L.; RAJOLA, F. Merger and Acquisitions in the Italian Banking Industry: Impacts on organization and Information Systems. Proceedings of the Annual Conference of the Scientific Commission on Organization. Zurique. Suiça, 2000.

McAFEE, A. Mastering the three worlds of information technology. Harvard Business Review, v.84, n.11, p. 141-149, 2006.

McKIERNAN, P.; MERALI, Y. Integrating information systems after a merger. Long Range Planning, v.28, n.4, p. 54-62, 1995.

MEHTA, M.; HIRSCHLEIM, R. Strategic alignment in mergers and acquisitions: theorizing IS integration decision making. Journal of the Association for Information Systems, v.8, n.3, p. 143-174, 2007.

MENDONZA, L.E.; PEREZ, M.; GRIMAN, A. Critical success factors for managing systems integration. Information Systems Management, v.23, n.2, Spring, 2006.

MERALI, Y.; McKIERNAN, P. The strategic positioning of information systems in post-acquisition management. Journal of Strategic Management Systems, v.2, n.2, p. 105-124, 1993.

MORTON, S. M. S. The corporation of the 1990s. New York: Oxford University Press, 1991.

PICOT, G. Economic and Business Law Parameters. In: PICOT, G. Handbook of international mergers and acquisitions. New York: PalgraveMacmillan,2002.

PEREZ, G. Adoção de Inovações Tecnológicas: um estudo sobre o uso de sistemas de informação na área de saúde. Tese de Doutorado. Universidade de São Paulo, Brasil,2006.

PIRES, M. G. A integração pós-fusão dos sistemas e da tecnologia da informação nas fusões e aquisições em instituições bancárias. Tese de Doutorado. Universidade de São Paulo, Brasil, 2011.

; MARCONDES, R. C. Conhecimento, inovação e competência em organizações financeiras: uma análise sob o ponto de vista de gestores de bancos. Revista de Administração Contemporânea (edição especial), v.89, p. 61-78,2004.

POLANYI, M. The tacit dimension. Gloucester: Peter Smith, 1983.

PORTER, M. E.; MILLAR, V. E. How information technology gives you competitive advantage. Harvard Business Review, v.63, n.4, p.149-159, 1985.

PRICEWATERHOUSECOOPERS DO BRASIL. Fusões e Aquisições no Brasil. Recuperado de: $<$ http://www.pwc.com.br/pt/publicacoes/servicos/assets/fusoes-aquisicoes/fusoes-aquisicoesdezembro-14.pdf $>$. Acesso em: 01/12/2014.

ROBBINS, S. S.; STYLIANOU, A. C. Post-merger systems integration: the impact on IS capabilities. Information \& Management, v.36, n.4, p. 205-212, 1999.

STEIN, M. A. Anatomy of a merger. Chief Information Officer Journal. v.5, n.5, p.34-37, 1993. 
STYLIANOU, A. C.; JEFFRIES, C. J.; ROBBINS, S. S. Corporate mergers and the problems of IS integration. Information \& Management, v.31, n.4, p. 203-213, 1996.

TURBAN, E.; McLEAN, E.; WETHERBE, J. Information Technology for Management. New York: John Wiley \& Sons, 1999.

WALSH, M.; ROEHDL, J.; DOYLE, A. L.; CHICKERMANE, N. Don't forget IT: eight simple ideas to help reduce IT-related M\&A risk. $M \& A$ Consultative Services. Deloitte Consulting, 2008.

WEILL, P.; BROADBENT, M. Leveraging the new infrastructure: how market leaders capitalize on information technology. Boston: Harvard Business School Press, 1998.

WIJNHOVEN, F.; SPIL, T.; STEGWEE, R.; A Fa, R. T. Post-merger IT integration strategies: an IT alignment perspective. Journal of Strategic Information Systems, v.15, n.1, p.5-28, 2006.

ZHAO, J. The IT integration of mergers \& acquisitions. Dissertação. Massachusetts Institute of Technology. Cambridge: Massachusetts, 2006.

ZOLLO, M.; SINGH, H. Deliberate learning in corporate acquisitions: post-acquisition strategies and integration capability in U.S. bank mergers. Strategic Management Journal, v.25, n.13, p. 1233-1256, 2004. 